\title{
ESKALASI KELOMPOK USAHA “BMD JAYA” MENUJU UKM UNGGULAN LANGKAT
}

\author{
Adek Cerah Kurnia Azis ${ }^{1)}$, Putri Sari Margaret Julianty Silaban²), \\ Joko Suharianto ${ }^{3)}$ \\ Universitas Negeri Medan ${ }^{1)}$ \\ Universitas Negeri Medan ${ }^{2}$ \\ Universitas Negeri Medan ${ }^{3)}$ \\ adekcerah@unimed.ac.id
}

\begin{abstract}
ABSTRAK
Tujuan utama dari Kegiatan Pengabdian Kepada Masyarakat ini, menyelesaikan permasalahan yang tengah dihadapi oleh mitra, permasalahan tersebut yakninya dalam hal merek dagang, pembukuan keuangan usaha, dan pemasaran produk. Dimana ketiga item ini yang menjadi prioritas yang tengah dihadapi oleh mitra, berdasarkan permasalahan yang ada tersebut, maka tim pengabdi memberikan solusi dari ketiga item permasalahan tersebut di atas, dengan melakukan pelatihan, pendidikan, pendampingan, sosialisasi, dan penyerahan alat dan bahan penunjang usaha mitra. Kegiatan ini dilakukan dalam hal pembuatan merek dagang dan inovasi pengemasan produk, perbaikan pembukuan keuangan, dan inovasi pemasaran produk berbasis online. Metode yang dilakukan dalam kegiatan ini yaitu dengan melakukan pendekatan dengan mitra. Adapun yang menjadi output pada kegiatan ini yaitu: a). Adanya merek dagang, model pengemasan baru yang menarik b). Pembukuan keuangan usaha mitra sudah baik dan benar, c). Model pemasaran usaha berbasis online, d). Serah terima alat dan bahan untuk penunjang kemajuan mitra, di sini usaha tersebut yaitu "UKM BMD" sebuah usaha yang bergerak dalam pembuatan kue-kue kering atau disebut juga dengan cemilan kering. Pada kegiatan ini luaran lainnya yang dicapai berupa e). Publikasi pada media online, dan f). Artikel dalam Jurnal Nasional ber-ISSN online dan cetak serta sudah terakreditasi Nasional.
\end{abstract}

Kata kunci: eskalasi, BMD, Langkat.

\begin{abstract}
The main purpose of the Community Service Activities is to solve the problems being faced by partners, the problems are in terms of trademarks, accounting of business finances, and product marketing. Where these three items are the priorities being faced by partners, based on the existing problems, the service team provides solutions to the three items mentioned above, by conducting training, education, mentoring, socialization, and the delivery of tools and supporting materials for business partners. This activity is carried out in terms of manufacturing trademarks and product packaging innovations, financial bookkeeping improvements, and online-based product marketing innovations. The method used in this activity is to approach partners. The outputs of this activity are: a). The is a trademark, an attractive new packaging model, b). Bookkeeping partners' financial business is good and right, c). Online-based business marketing model, d). Handover of tools and materials to support the progress of partners, here the business is "UKM BMD" a business engaged in making pastries or also called dry snacks. In this activity other outcomes achieved in the form of e). Publication on online media, and f). Articles in the ISSN National Journal are online and printed and are National accredited.
\end{abstract}

Keywords: escalation, BMD, Langkat.

\section{PENDAHULUAN}

Kabupaten Langkat adalah merupakan salah satu kabupaten yang ada di Sumatera Utara, dengan luas wilayah 6.272 Kilo Meter Persegi dan dengan Jumlah penduduk 902.986 jiwa (Profil Kabupaten Langkat dalam
Suharianto, 2020: 19). Kabupaten ini bisa dikatakan Kabupaten yang potensial dalam menghasilkan Usaha Kecil Menengah (UKM) dalam berbagai industrinya. Di Kabupaten ini ada sebuah UKM yang bisa dikatakan cukup berkembang dari tahun ke 
tahunnya, usaha ini bernama "BMD JAYA", usaha yang berdiri sejak 5 tahun terakhi ini dipimpin oleh Bapak Misdi. Bapak Misdi memiliki 5 orang karyawan yang berperan aktif untuk kemajuan UKM ini tentunya. Hasil olahan rasa dari usaha ini tidak perlu diragukan lagi, hal ini terbukti dengan jangkauan pemasaran produk ini hingga ke luar Kabupaten Langkat. Supaya usaha ini bisa berkembang semakin pesat ada beberapa hal yang perlu untuk dikonsentrasikan dalam hal pembaharuan dari segi kualitas, sistem, dan cara kerja pengelolaan produk yang dihasilkan, keuangan, dan pemasaran produk. Terkadang seorang konsumen ingin untuk membeli produk dari UKM ini dengan jumlah yang cukup besar, namun hal tersebut tidak bisa dilakukan, dikarenakan tidak adanya merek dagang pada pengemasan produk, sebuah merek dagang tentunya memiliki konten merek usaha (brand), ilustrasi produk, masa berlaku, komposisi, kehalalan produk, nomor kontak pemilik usaha, hingga alamat lengkap rumah produksi. Hal inilah yang tidak dimiliki oleh produk yang dihasilkan ole UKM ini. Kemasan dapat didefenisikan sebagai seluruh kegiatan merancang dan memproduksi wadah atau bungkus atau kemasan suatu produk. Kemasan meliputi tiga hal, yaitu merek, kemasan itu sendiri, dan label (Cenadi, 2004: 93).

$$
\text { Selanjutnya Wirya }
$$

mengatakan bahwa sebuah kemasan harus mempunyai daya tarik, digolongkan menjadi dua, yakni: 1). Daya tari visuak dan 2). Data tarik praktis. Sedapat mungkin sebuah kemasan harus tampil menarik agar mampu menarik perhatian calon konsumen (Natadjaja, 2007: 21).

Berdasarkan penjelasan di atas bahwa betapa pentingnya sebuah kemasan dalam sebuah usaha, dimana dapat disimpulkan kemasan adalah kegiatan merancang dari awal hingga akhir sebuah bungkus atau pembungkus sebuah produk yang terkandung didalamnya merek produk itu sendiri, kemasan itu sendiri, laber produk itu sendiri, dan alat yang digunakan untuk mempacking produk itu sendiri, yang dibuat semenarik mungkin dengan tujuan untuk membangkitkan stimulus calon konsumen untuk membeli produk tersebut.

Selanjutnya dari segi pembukuan keuangan, UKM ini masih menggunakan perhitungan manual, hasil dari wawancara dengan Bapak Misdi via Handphone (HP) pada hari Senin, tanggal 11 Mei 2020 jam 17:00 WIB, mengungkapkan "kadang terjadi kekeliruan dalam perhitungan laba dan pengalokasian gaji karyawan, karena menghitungnya secara manual dengan coretan pensil, tidak jarang juga hasil coretan ini hilang dan terhapus terkadang tercampurnya pembukuan keuangan modal dengan laba usaha. Program apa yang harus digunakan untuk membuat pembukuan keuangan yang baik dan benar, hal ini yang menjadi pertanyaan saya", begitu ungkap Bapak Misdi.
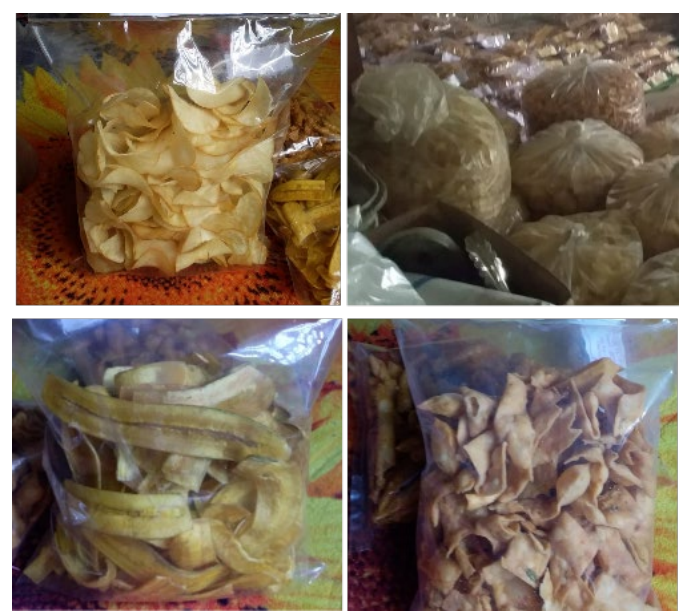

Gambar 1. Produk UKM BMD JAYA Masih Polos (Sumber: Adek Cerah Kurnia Azis, 2019) 
Bertolak dari realita yang ada di atas tentang permasalahan yang tengah dihadapi oleh mitra maka dapat diidentifikasi yaitu mengenai 1). Merek Dagang dan 2). Pembukuan Keuangan Usaha. Kedua hal ini merupakan masalah yang bisa diselesaikan dengan sentuhan solusi terbaik dan penuh keuletan dimana "sebuah keuletan, semangat, dan kreativitas mampu membangun usaha dari nol" (Sinamarata dalam Yuni, 2019: 344). Modal itu semua akan mampu membuat usaha ini menjadi maju dan ditambah dengan mendatangkan ahli atau pakar yang bisa memberikan solusi dan menyelesaikan permasalahan yang dihadapi oleh mitra.

\section{METODE PELAKSANAAN}

Berikut metode yang digunakan dalam kegiatan Pengabian Kepada Masyarakat ini, 1). Persiapan, 2). Pendekatan, 3). Partisipasi mitra, dan 4). Evaluasi Pelaksanaan Program.

Tahapan persiapan ini melakukan persiapan dengan a). Melakukan observasi awal ke tempat mitra, b). Melakukan sosialisasi dengan mitra tentang rencana kegatan yang akan dilakukan, c). Diskusi dengan mitra menentukan jadwal dan tempat kegiatan, dan d). Melakukan kegiatan sesuai dengan rencana kegiatan, jadwal kegiatan, dan tempat kegiatan.

Sementara untuk pelaksanaan kegiatan yang dilakukan a). Melakukan Focus Group Discussion $(F G D)$ dengan mitra dan b). Melakukan kegiatan pelatihan, pendampingan, pendidikan, dan sosialisasi tentang merek dagang dan pembukuan keuangan.

Tahap pendekatan yang dilakukan guna menyelesaikan persoalan mitra, sebagai berikut: observasi lapangan ke lokasi mitra, berkomunikasi dengan mitra, mengelompokan masalah mitra, mencari problem solving, penentuan lokasi kegiatan (dalam hal ini mitra berperan untuk menfasilitasi tempat kegiatan), $F G D, \quad$ pelatihan, pendampingan, pendidikan, sosialisasi, dan evaluasi.

Tahapan partisipasi mitra, dimana mitra berperan penting dalam keberhasilan sebuah Program Pengabdian Kepada Masyarakat, mitra ikut serta dalam berpartisipasi untuk kesuksesan kegiatan pengabdian ini, a). Mitra menfasilitasi tempat kegiatan dan ikut serta dalam dan selama kegiatan berlangsung.

Tahapan evaluasi pelaksanaan kegiatan, pada tahapan ini melihat berapa \% (persen) keberhasilan program berdasarkan indikator-indikator yang diamati dan faktor kendala apabila program Pengabdian Kepada Masyarakat yang dilakukan belum berhasil dan belum sesuai dengan yang diharapkan, faktor kendala inilah yang perlu untuk dibenahi kedepannya sebagai pengalaman berharga bagi tim untuk lebih baik lagi pada kegiatan-kegiatan berikutnya.

\section{HASIL DAN PEMBAHASAN}

Kegiatan Pengabdian Kepada Masyarakat ini menghasilkan luaran sebagai berikut: 1). Merek dagang dan 2). Pembukuan keuangan usaha sudah berbasis digital.

Berikut yang dihasilkan selama kegiatan Pengabdian Kepada Masyarakat dilakukan: 1). Merek dagang: 


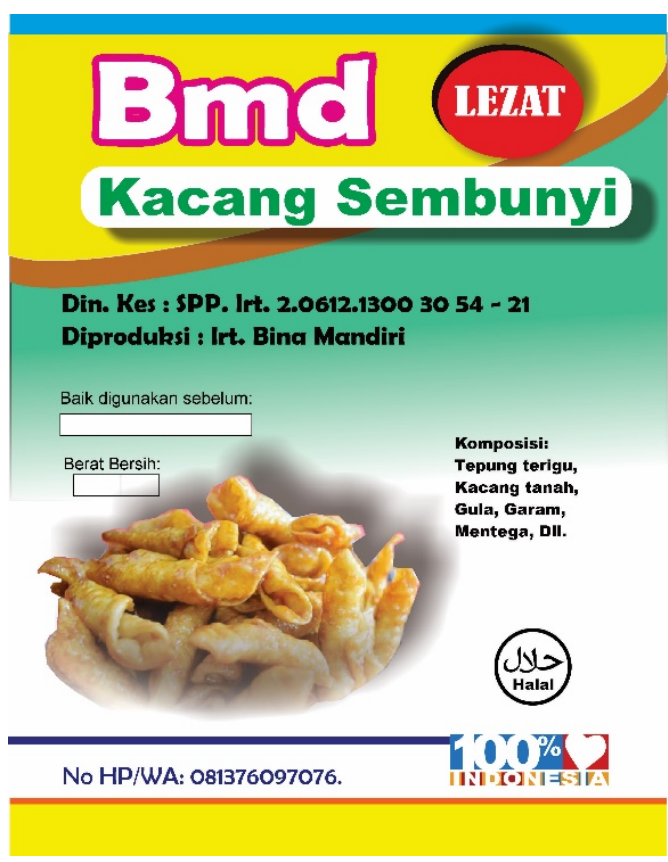

Gambar 2. Desain Bmd Kacang Sembunyi

(Sumber: Adek Cerah Kurnia Azis, 2019)

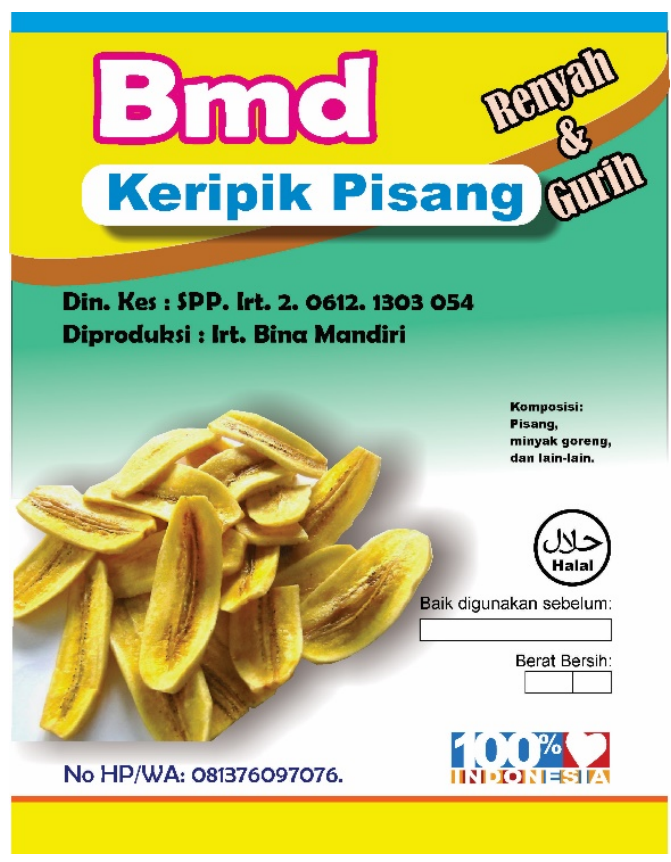

Gambar 3. Desain Bmd Keripik Pisang (Sumber: Adek Cerah Kurnia Azis, 2019)

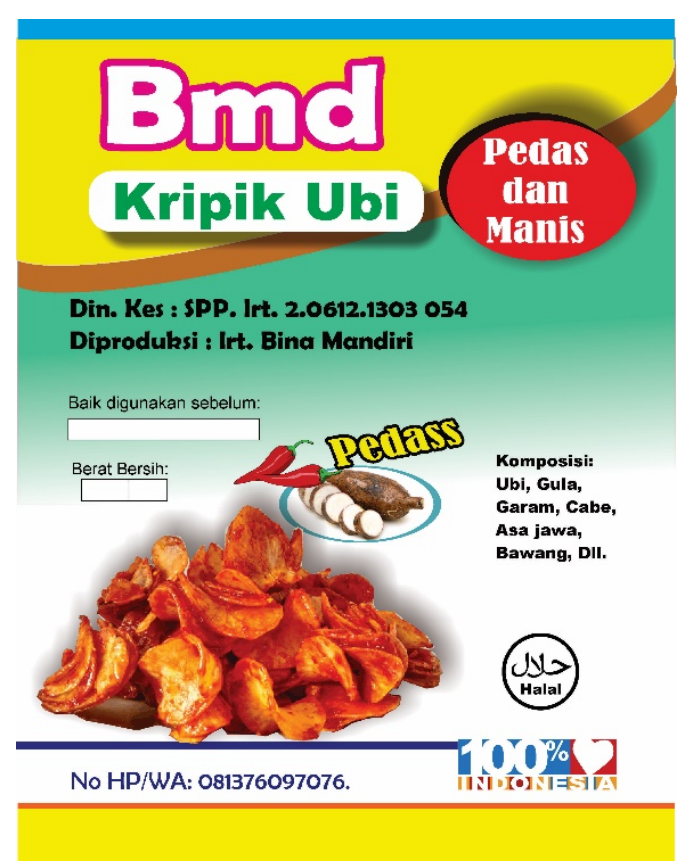

Gambar 4. Desain Bmd Keripik Ubi Pedas dan Manis (Sumber: Adek Cerah Kurnia Azis, 2019)

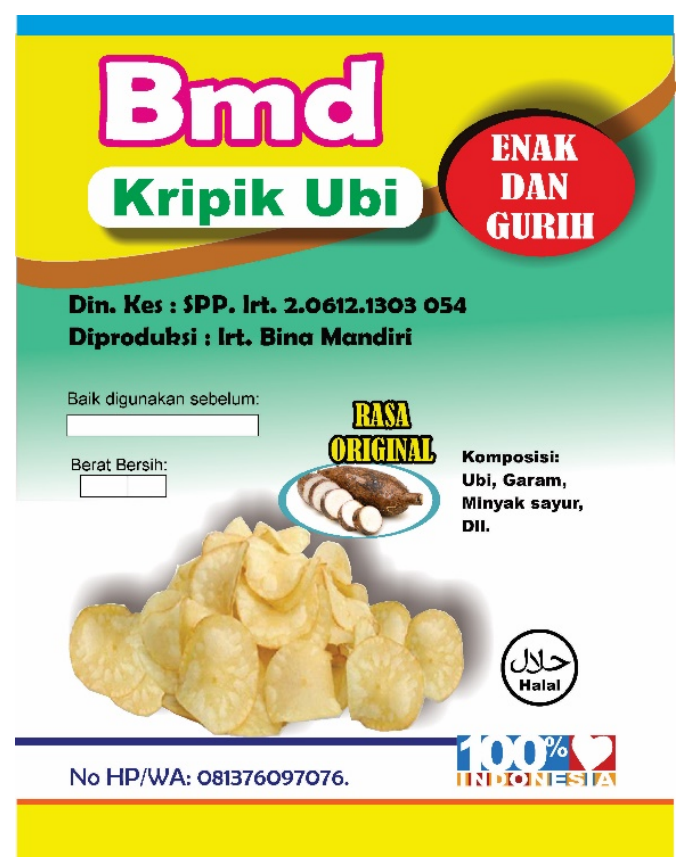

Gambar 5. Desain Bmd Keripik Ubi Original (Sumber: Adek Cerah Kurnia Azis, 2019) 


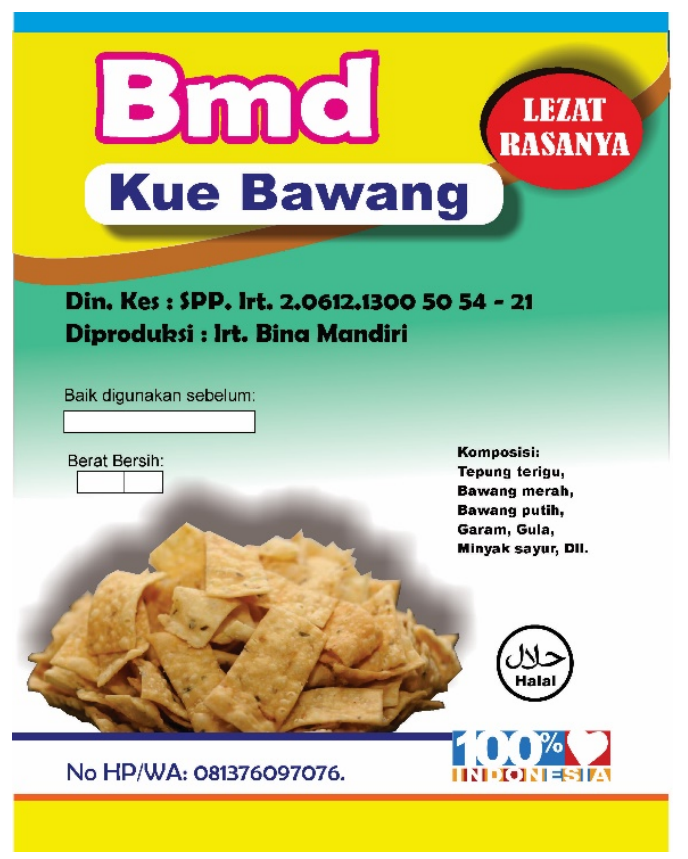

Gambar 6. Desain Bmd Kue Bawang (Sumber: Adek Cerah Kurnia Azis, 2019)

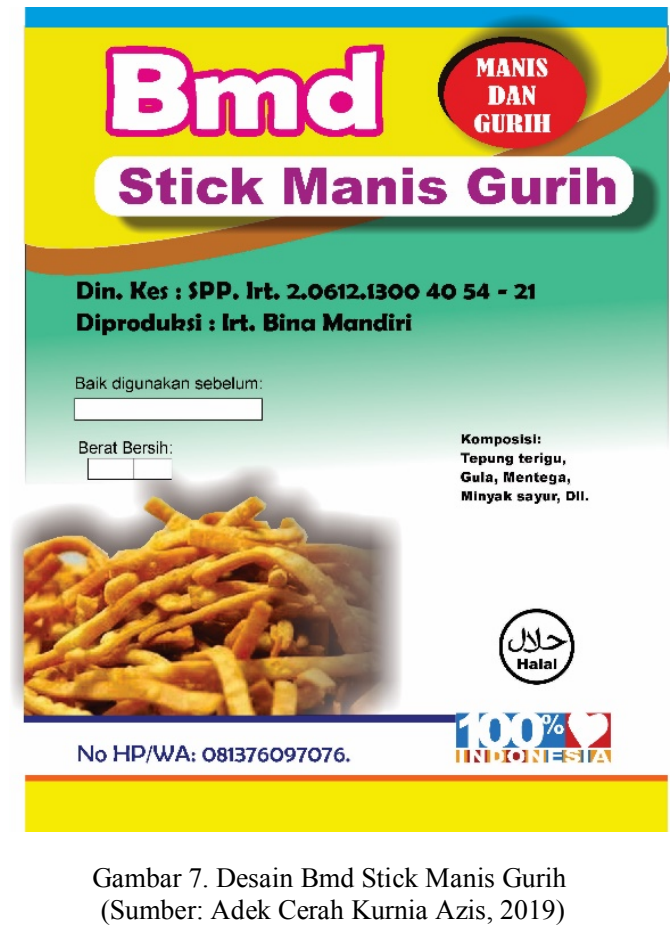

2). Pembukuan keuangan usaha, dimana mitra sudah menggunakan teknologi komputer dalam pengolahan laporan keuangan usaha, yang sebelumnya hanya dilakukan dengan manual.

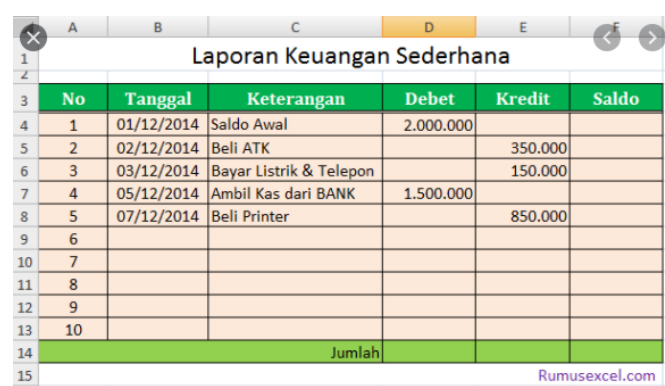

Gambar 8. Laporan Pembukuan Keuangan Usaha (Sumber: Adek Cerah Kurnia Azis, 2019)

Selama kegiatan berlangsung ada pakar yang berperan aktif dalam peningkatan kemajuan usaha mitra, pakar yang ada tersebut memiliki keahlian dalam berbagai bidang yang sangat berkorelasi dengan penyelesaian masalah yang tengah dihadapi oleh mitra tentunya, seperti 1). Ahli dalam desain kemasan dan pengemasan, dalam upaya mendesain merek dagang dan inovasi pengemasan produk menjadi lebih menarik lagi, yaitu dengan adanya pelatihan, pendidikan, pendampingan, dan sosialisasi yang langsung mendatangkan pakar dari Seni Rupa dan 2). Ahli Pembukuan Keuangan yang aktif dalam kegiatan pelatihan, pendidikan, dan pendampingan yang dilakukan pada berbagai kegiatan tentang penyusunan laporan keuangan, maka dengan itu perlu didatangkan pakar dalam bidang ekonomi, terkhusus perekonomian usaha kecil menengah yang langsung mendatangkan dari Dosen Jurusan Ekonomi Universitas Negeri Medan.

\section{KESIMPULAN}

Adapun tujuan utama yang diharapkan dalam kegiatan Pengabdian Kepada Masyarakat ini, yakninya memajukan usaha mitra dalam segi kualitas produk dan ekonomi usaha menjadi meningkat tentunya. Dimana sebelumnya usaha mitra belum memiliki merek dagang 
dan pembukuan keungan yang masih manual, setelah tim dari Universitas Negeri Medan turun ke lapangan hal tersebut menjadi berubah, dimana untuk saat sekarang mitra sudah memiliki merek usaha yang menarik dan pembukuan keuangan usaha yang sudah berbasis digital. Hal ini tentunya dapat meningkatkan kualitas produk dan peningkatan perekoniam usaha mitra.

\section{REFERENSI}

Cenadi, C. S. (2004). Peranan Desain Kemasan Dalam Dunia

Pemasaran. Nirmana, 2(2), 92-103.

Natadjaja, L. (2009). Analisa Elemen Grafis Desain Kemasan Indomie Goreng Pasar Lokal dan Ekspor. Nirmana, 9(1), 2029.

Suharianto, J., Azis, A. C. K., \&

Silaban, P. S. M. J. (2020). Virgin Coconut Oil (VCO) Menuju Produk Unggulan Kabupaten Langkat. Amaliah: Jurnal Pengabdian Kepada Masyarakat, 4(1), 18-22.

Yuni, R., Mesra, M., Hastuti, P., \&

Azis, A. C. K. (2019). Pemberdayaan Usaha Kecil Menengah (UKM) di Desa Kolam Kabupaten Deli Serdang. Amaliah: Jurnal Pengabdian Kepada Masyarakat, 3(2), 344-348.

Wirya, Iwan. (1999). Kemasan Yang Menjual. Jakarta: PT. Gramedia Pustaka Utama. 